\title{
A BED OF PEAT IN LONDON CLAY?
}

SrR,-I observe in the July Number of the "Journal of the Society of Industrial Chemistry" a notice of a short paper in which the use of the term "London Clay" is erroneous, or at least appears so to me. The writers mention and describe a bed of peat at the works of the New Thames 'Iunnel " underlying the London Clay." As the bed in question is only 12 feet below the surface this is scarcely possible unless there is some misprint. The peat is "composed chiefly of branches and truuks of trees, twigs, etc. It is about two feet thick."

It seems to me that the writers are referring to one of the exposures of the buried forest or peat bed so common around the southern coast of England. The error, if such it is, would be of slight importance were it not for the concluding sentence, "it has geological interest as showing that at a period anterior to the formation of the London Clay an abundant growth of trees and shrubs extended from some distance inland right down to the water's edge in this locality."

It seems from this that the writers have also mistaken some recent and local stratum for the "London Clay" of geology. Perhaps some one nearer to the spot than I am can correct the error if there is one.

E. W. Claypole, D.Sc., B.A. (Lond.)

Bughter Coll., Akron, Ohro.

\section{Note by Mr. F. C. J. Spurrell, F.G.S.}

Sir,-I bave read Mr. Claypole's letter. His surmise that the bed of peat 12 feet below the surface at the spot described is part of the recent forest-beds of the South of England is correct. It is above and in no way connected with the London Clay. This term, applied to the alluvial blue clays of the Thames, was in use in Brunel's days, and I should think the author of the paper referred to bad been reading up some old accounts of embanking, etc., of the last century, when the blue clay, wherever found, was supposed to be the same as the mass underlying London.

Betvedere, Kent, 24 th Sept., 1892.

F. C. J. S.

\section{THE PHOSPHATIC CHALK AT TAPLOW.}

Sir,-Since, so far as I am aware, none but microscopic fish remains have been recorded from the Taplow phosphatic chalk, it may be of interest to mention that, on July 8th last, I found in the $8 \mathrm{ft}$. bed at Taplow Court Lodge, described by Mr. Strahan (Quart. Journ. Geol. Soc., 1891, p. 356), the detached crown of a shark's tooth $\frac{2}{3}$ inch long. Although this is insufficient for accurate determination, Mr. A. Smith Woodward informs me that it most nearly resembles the form of tooth described by Agassiz as Odontaspis subulata, but is rather large for that species.

Bernard Hobson.

Grological Department, Owen's College, Manchegter. September 13th, 1892. 